\title{
CYTOKINES PROFILE IN EXPERIMENTAL CONTACT ALLERGIC DERMATITIS AND USE OF NANOENCAPSULATED AGENTS
}

\author{
I. I. Khudan-Tsilo, O. O. Shevchuk, M. M. Korda \\ I. HORBACHEVSKY TERNOPIL STATE MEDICAL UNIVERSITY, TERNOPIL, UKRAINE
}

Background. Inflammation, oxidative and nitro-oxidative stress are the essentials of the pathogenesis of contact allergic dermatitis as well as cytokines imbalance.

Objective. The concentration of TNF- $a, I L-1 \beta, I L-4$ and IL-10 in blood serum of rats with nickel-induced contact allergic dermatitis was evaluated to determine whether it correlated with the use of free and nanoencapsulated preparations of betamethasone, superoxide dismutase (SOD) and potent highly selective inhibitor of iNOS (1400W).

Methods. To induce contact dermatitis (CD), $5 \%$ nickel sulfate was used for 12 days. Experiments were performed on white inbred male rats, $180-220 \mathrm{~g}$ of body mass. All rats were divided into 10 groups $(n=10)$. Group I - the control one; II - the animals with CD; III - the rats with CD treated with empty polymeric chitosan nanoparticles; groups IV-VI - the rats with CD treated with free SOD, 1400W and betamethasone; groups VII-IXthe rats administered with nanoencapsulated SOD, 1400W and betamethasone; $X-C D+$ nano-composition of all agents.

Results. The statistically higher serum concentrations of TNF- $a, I L-1 \beta$ and decrease of IL-4 and IL-10 in experimental contact dermatitis is proved in comparison with the healthy rats. Mono-treatment with betamethasone, SOD and 1400W is efficient, but the use of nanoparticles loaded with these preparations surpasses its effects. The use of the combination of all nanoencapsulated medicines is the most effective.

Conclusions. Chitosan nanoparticles loaded with topical anti-inflammatory glucocorticoid, and inhibitors of oxidative and nitro-oxidative stress is a promising method for treatment of allergic contact dermatitis and can be recommended for further research and use in clinics.

KEY WORDS: contact nickel dermatitis; cytokines; nanoparticles; betamethasone; SOD; $1400 \mathrm{~W}$.

\section{Introduction}

Contact dermatitis (CD) frequency has been rising recently $[1,2]$. Its two types are differentiated: triggered by antigens as allergic contact dermatitis and by obligatory cutaneous irritants - irritant contact dermatitis (nonimmunologic driven reaction) [3]. All types of dermatitis (atopic, psoriatic, allergic, etc.) are challenge for health care system because of chronic and relapsing character. It is forth reason for doctor's visiting among all skin disorders [4]. Today the first choice and the mainstay of dermatitis drug therapy are topical glucocorticoids (TGs): betamethasone, dexamethasone, fluocinolone, triamcinolone, etc. In spite of their high efficacy a lot of side effects (systemic and local) are common: skin atrophy, acneiform eruption, striae, and telangiectasia, as well as hypothalamic-pituitary-adrenal axis

Corresponding author: Oksana Shevchuk, Associate professor, Department of Pharmacology and Clinical Pharmacology I. Horbachevsky Ternopil State Medical University, 1 Maydan Voli, Ternopil, 46000, Ukraine

E-mail: shevchukoo@tdmu.edu.ua

Phone number: +38(0352)52-44-92 suppression, glaucoma development, high risks of thrombosis and others $[5,6]$.

One more serious challenge for dermatitis treatment is transdermal delivery of active components. Skin is a prime barrier against a lot of environmental physical, chemical, and biological stressors (ultraviolet irradiation, bacteria, viruses, allergens, etc.). Stratum corneum, claudins and occludins of tight junctions are crucial in defense, but also impede the absorption of topical medicines [7]. Nanoencapsulated medications have been developed as a vehicle into the deeper skin layers and demonstrated its benefits [8-10]. Nanotechnology through the reduced particle size improves the absorption and concentration of the drug in the target tissue, its pharmacokinetic parameters and long-term release of the medication at the target site [11].

It is established at present that even regular use of TGs does not prevent the relapse of CD and does not provide the appropriate control of its severity [12]. Cytokines are crucial in pathogenesis of different types of dermatitis (allergic, atopic, etc.). Contact allergic dermatitis 
is mediated via T lymphocytes. Contacting the allergens epithelial cells may produce mediators, which intensify the cascade of immune response [13]. The combination of sensitized $T$ cell plus antigen releases cytokines cascade and lead to inflammation [14].

The objective of the research is to study the cytokines profile in experimental allergic contact dermatitis and its correction with nanoencapsulated steroid anti-inflammatory agent, antioxidant and iNOS inhibitor.

\section{Methods}

Animals and experimental design. Experiments were performed on white inbred male rats $180-220 \mathrm{~g}$ of body mass. All rats were divided into 10 groups, 10 animals in the each one. group I - the control one involved the animals sensitized only with solid lanoline base; group II - the animals with contact dermatitis (CD) induced by sensitization with $5 \% \mathrm{NiSO}_{4}$ dissolved in the base; group III - the rats with $C D$ treated with empty polymeric chitosan nanoparticles; groups IV-VI involved the rats with CD treated with free SOD, 1400W and betamethasone accordingly; groups VII-IX - the rats, which were administered with nanoencapsulated SOD, 1400W and betamethasone; group $X-C D+$ nano-composition of SOD, betamethasone and 1400W.

To induce the contact dermatitis the hair on the dorsal area, $4 \times 4 \mathrm{~cm}$ in size, was removed and the cleaned skin area was administered with $4 \mathrm{~g}$ of solid lanoline composition containing $5 \%$ nickel sulfate for 12 days. All correctors were used for one week after the development of $C D$ twice a day.

We used Sigma-Aldrich (USA) betamethasone 17,21-dipropionate, PEGylated superoxide dismutase (SOD) and $\mathrm{N}$-([3-(Aminomethyl) phenyl]methyl)ethanimidamide dihydrochloride (1400W)-potent highly selective inhibitor of iNOS. Chitosan nanoparticles loaded with above-mentioned preparations were prepared according to the method described by Hussain Z., et al. [15]. Chitosan solution $(25 \mathrm{~mL}, 0.2 \% \mathrm{w} / \mathrm{v}$, prepared in $1 \% \mathrm{v} / \mathrm{v}$ acetic acid, $\mathrm{pH}$ 5.0) was incubated with Betamethasone solution $(1 \mathrm{mg} / \mathrm{mL}$ in a $30: 70$ mixture of ethanol/water) or $1400 \mathrm{~W}(1 \mathrm{mg} / \mathrm{mL})$ or SOD solution $(10 \mathrm{mg} / \mathrm{mL})$ stirring for 30 minutes. Loaded nanoparticles were spontaneously formed by adding $10 \mathrm{~mL}$ of pentasodium tripolyphosphate solution $(0.1 \%$ $\mathrm{w} / \mathrm{v}$, in distilled water) dropwise with constant stirring at $700 \mathrm{rpm}$. The nanoencapsulated preparations were harvested by ultracentrifugation $(28,000 \mathrm{rpm})$ for 30 minutes and subsequently resuspended. The size of nanoparticles was determined using the morphometric program Video-Test-5.0, Kappa ImageBase, and it was 40-100 nm.

All procedures for the animals were performed according to the rules and requirements of European Convention for the Protection of Vertebrate Animals Used for Experimental and Other Scientific Purposes, Directive 2010/63/EU and were approved by local TSMU Ethic Committee. The rats were euthanized under the ketamine anesthesia on the $20^{\text {th }}$ day of examination. Amounts of cytokines in blood serum were evaluated by ELISA test (RayBiotech Inc., Norcross, GA, USA). The concentrations of TNF- $\alpha$, IL-1 $\beta$, the Th2specific cytokines IL-4 and IL-10 were analyzed.

Statistical analysis. The data are presented as mean \pm SE standard error. Statistical analysis was performed by the Statistica 10.0 (StatSoft Inc., USA) program. The distribution of indices was estimated using Shapiro-Wilk normality test. The significance of the results was determined by the Mann-Whitney U-test and ANOVA-test. A probability level of less than 0.05 was considered as statistically significant.

\section{Results}

It has been established that in $C D$, induced by nickel sulfate, blood serum concentration of
Development of nickel-induced contact allergic dermatitis day $1-12$

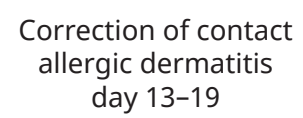

Correction of contact allergic dermatitis day $13-19$

Necropsy, blood samples day 20

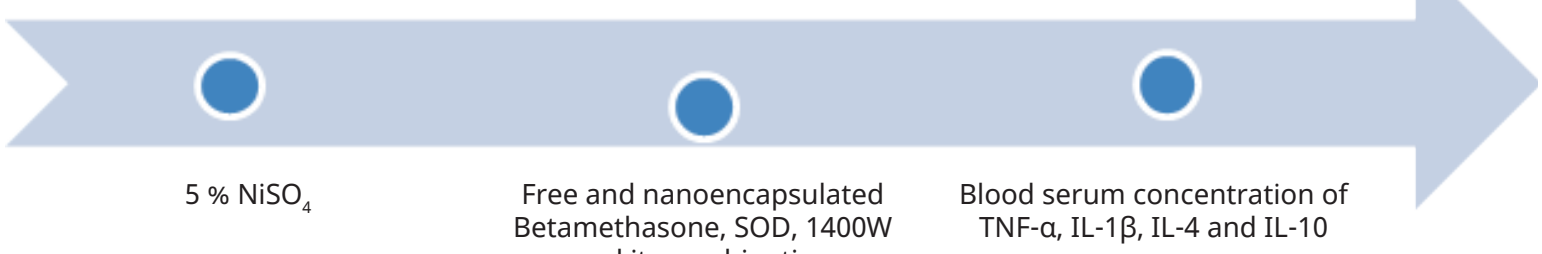
and its combination

Fig. 1. Schematic diagram of experimental design. 
pro-inflammatory cytokines TNF- $\alpha$ and IL-1 $\beta$ significantly increased in 5.5 and 3.7 times compared to the intact rats (Table 1). Anti- inflammatory Th2-specific cytokines IL-10 and IL-4 concentration was significantly lower, in 2.3 times and 2.4 times respectively.

Table 1. Blood serum concentration of cytokines in experimental contact nickel dermatitis, $M \pm m, n=10$

\begin{tabular}{|c|c|c|c|c|c|c|c|c|c|c|}
\hline $\begin{array}{l}\text { Inter- } \\
\text { leukins }\end{array}$ & $\begin{array}{c}\text { Intact } \\
\text { rats }\end{array}$ & $C D$ & 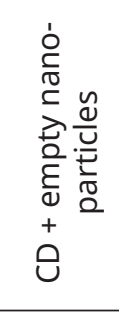 & 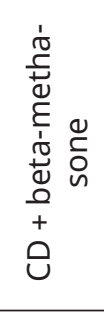 & 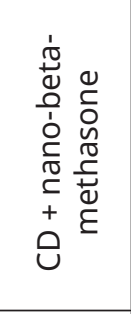 & $\begin{array}{l}0 \\
\text { ஸ } \\
+ \\
\stackrel{0}{u}\end{array}$ & 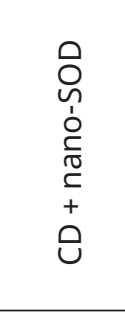 & $\begin{array}{l}3 \\
\text { Oे } \\
\stackrel{+}{+} \\
+ \\
+ \\
ن\end{array}$ & 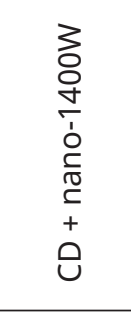 & 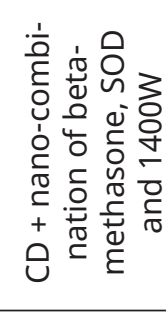 \\
\hline $\begin{array}{l}\text { TNF-a, } \\
\mathrm{pg} / \mathrm{ml}\end{array}$ & $\begin{array}{c}7.48 \\
\pm 0.56\end{array}$ & $\begin{array}{c}41.16 \\
\pm 4.10\end{array}$ & $\begin{array}{c}40.54 \\
\pm 3.98 *\end{array}$ & $\begin{array}{l} \pm 2.30 \\
\star, \star \star\end{array}$ & $\begin{array}{c}20.94 \\
\pm 1.16 \\
\star_{,}{ }^{*}, \#^{1}\end{array}$ & $\begin{array}{c}35.48 \\
\pm 1.95 \\
\star \star \star *\end{array}$ & $\begin{array}{c}30.22 \\
\pm 2.02 \\
*, * *, \#^{2}\end{array}$ & $\begin{array}{c}36.22 \\
\pm 1.78 \\
\star, \star \star\end{array}$ & $\begin{array}{c}30.12 \\
\pm 1.56 \\
*, * \star, \#^{3}\end{array}$ & $\begin{array}{c}12.88 \pm 1.28 \\
*, * *, y^{123}\end{array}$ \\
\hline $\begin{array}{l}\text { IL-1 } 1 \beta, \\
\mathrm{pg} / \mathrm{ml}\end{array}$ & $\begin{array}{l}10.46 \\
\pm 0.88\end{array}$ & $\begin{array}{c}37.98 \\
\pm 2.42 *\end{array}$ & $\begin{array}{c}35.88 \\
\pm 3.36 *\end{array}$ & $\begin{array}{c}24.77 \\
\pm 1.75 \\
\star, \star \star\end{array}$ & $\begin{array}{c}19.35 \\
\pm 1.28 \\
*, * \star, \#^{1}\end{array}$ & $\begin{array}{c}31,32 \\
\pm 1.54 * \\
* \star\end{array}$ & $\begin{array}{c}26.45 \\
\pm 1.54 \\
\star \star \star * *, \#^{2}\end{array}$ & $\begin{array}{c}32.16 \\
\pm 1.98 \text { * }\end{array}$ & $\begin{array}{c}26.66 \\
\pm 1.38 \\
*, * *, \#^{3}\end{array}$ & $\begin{array}{c}14.48 \pm 1.34 \\
*, * *, y^{123}\end{array}$ \\
\hline $\begin{array}{l}\mathrm{IL}-10, \\
\mathrm{pg} / \mathrm{ml}\end{array}$ & $\begin{array}{l}12.05 \\
\pm 1.08\end{array}$ & $\begin{array}{c}5.24 \\
\pm 0.42 *\end{array}$ & $\begin{array}{c}5.15 \\
\pm 0.42 *\end{array}$ & $\begin{array}{c}7.54 \\
\pm 0.52 \\
\star, \star \star\end{array}$ & $\begin{array}{c}8.96 \\
\pm 0.32 \\
*, * *, \#^{1}\end{array}$ & $\begin{array}{c}6.88 \\
\pm 0.50 \\
*, * * \\
\end{array}$ & $\begin{array}{c}7.88 \pm \\
0.64 \\
\star, \star \star\end{array}$ & $\begin{array}{c}6.32 \\
\pm 0.44 *\end{array}$ & $\begin{array}{c}8.48 \\
\pm 0.46 \\
\star, \star *, \#^{3}\end{array}$ & $\begin{array}{c}10.33 \pm 0.48 \\
* *, y^{123}\end{array}$ \\
\hline $\begin{array}{l}\text { IL-4, } \\
\mathrm{pg} / \mathrm{ml}\end{array}$ & $\begin{array}{l}19.26 \\
\pm 1.88\end{array}$ & $\begin{array}{c}8.02 \\
\pm 0.78 *\end{array}$ & $\begin{array}{c}7.68 \\
\pm 0.66 *\end{array}$ & $\begin{array}{c}11.43 \\
\pm 0.45 \\
\star, \star \star\end{array}$ & $\begin{array}{c}13.16 \\
\pm 0.58 \\
\star \star \star *\end{array}$ & $\begin{array}{c}10.04 \\
\pm 1.00 *\end{array}$ & $\begin{array}{c}11.25 \\
\pm 0.78 \\
\star \star \star *\end{array}$ & $\begin{array}{c}11.14 \\
\pm 0.32 \\
\star \star \star *\end{array}$ & $\begin{array}{c}13.26 \\
\pm 0.44 \\
*, * *, \#^{3}\end{array}$ & $\begin{array}{c}15.68 \pm 0.77 \\
* *, y^{123}\end{array}$ \\
\hline
\end{tabular}

Notes: statistical significance $p<0.05$ compared to: *intact rats; $* * C D$ rats; $\# 1$ - rats with $C D$ treated with free form of betamethasone, \#2 - free form of SOD, \#3 - free form of 1400W, $y^{1}$ - nanoencapsulated betamethasone, $y^{2}$ - nanoencapsulated SOD, $y^{3}$ - nanoencapsulated 1400W.

The use of empty nanoparticles did not cause any significant changes in the indices. Use of each nanoencapsulated agent was more efficient to restore the cytokines imbalance in comparison with free form usage. But the most prominent effect was caused by the combination of all three nanoencapsulated correctors.

Betamethasone is a topical corticosteroid of high potency. Its free form caused positive changes in cytokines profile: the decrease in pro-inflammatory TNF- $\alpha$ and IL-1 $\beta$ concentration by 34.5 and $34.8 \%$; and increase of antiinflammatory IL-10 and IL-4 - by 43.9 and $42.5 \%$ was evidenced. But nanoencapsulated TG was more effective and surpassed its free form efficacy.

TNF- $\alpha$ and IL- $1 \beta$ rates were statistically significantly lower in this group in comparison with CD group by 49.1 and $49.05 \%$; in comparison with its free form by 22.4 and $21.9 \%$.

Also the increase in anti-inflammatory interleukins IL-10 and IL-4 concentration was evidenced in group $C D+$ nano-betamethasone: by 71.0 and $64.1 \%$ in comparison with pathology; and by $18.8 \%$ for IL-10 in comparison with free form of TG.
The same tendency was for free and nanoencapsulated forms of SOD. The use of free SOD caused decreased concertation of TNF-a and IL- $1 \beta$ by 11.4 and $17.5 \%$; and increased rates of IL-10 and IL-4 by 31.3 and $25.2 \%$ accordingly. Nanoencapsulated SOD surpassed the activity of its free form in decreasing of concentration of pro-inflammatory cytokines. The rate of TNF-a was statistically significantly lower by $17.2 \%$, IL-1 $\beta$ - by $15.5 \%$. But there was a positive tendency only in correction of anti-inflammatory interleukins indices.

Highly selective inhibitor of iNOS was also quite efficient. The concentration of TNF-a decreased by $9.6 \%$ in use of its free form; and by 26.8 and $29.8 \%$ - of nanoencapsulated $1400 \mathrm{~W}$ accordingly. The last rates were statistically significantly improved by $19.1 \%$ for TNF- $\alpha$ and $17.0 \%$ - for IL-1 $\beta$ in comparison with $\mathrm{CD}+1400 \mathrm{~W}$ group. IL-4 concentration increased by $38.9 \%$ in use of free $1400 \mathrm{~W}$; and by $65.3 \%$ of nanoencapsulated one in comparison with control pathology (the last index was higher by $19.0 \%$ compared to CD $+1400 \mathrm{~W}$ group). Value of IL-10 was statistically significantly different only in case of use of nano-form of 1400W by 
$61.8 \%$ in the control group and by $34.2 \%$ in CD $+1400 \mathrm{~W}$ group.

The best results were evidenced in the group CD + nano-combination of betamethasone, SOD and 1400W. The combination of all nanoencapsulated agents was the most efficient in restoring of cytokines balance in comparison with mono-use of each corrector (table 1).

\section{Discussion}

Among a lot of allergens, nickel is one of the most common metals responsible for allergic CD. Its regular contacting for hypersensitive persons leads to a delayed-type hypersensitivity reaction and up to $20 \%$ of the general population may be affected in Europe [16-18]. High frequency of positive nickel patch tests and high serum nickel concertation are also observed in people with intrinsic atopic dermatitis [19].

Pathogenesis of allergic contact dermatitis includes sensitization (or induction) and elicitation (or efferent) phases, which are innate (opposite to contact irritant dermatitis) [20]. It is established at present that cytokines are crucial in inflammation, including immuneinvolved dermatitis [21-23].

A lot of skin cells are able to produce cytokines [24] (Table 2). Dermal dendritic cells are crucial in the process of activating naive T cells; after contacting the allergen Langerhans cells start to synthesize IL-1 $\beta$ mRNA and to release the protein; then, keratinocytes are activated and release TFN- $\alpha$ and GM-CSF [25].

Table 2. Cytokines developed by epidermal cells

\begin{tabular}{|c|c|}
\hline Epidermal cells & $\begin{array}{l}\text { Cytokine (constitutive } \\
\text { or inducible expression) }\end{array}$ \\
\hline Keratinocytes & $\begin{array}{l}\text { IL-1 } \alpha, \text { IL-1 } \beta, \text { IL-1 RA, IL-3 } \\
\text { (mouse), IL-6, IL-7, IL-8, IL-10, } \\
\text { IL-12, IL-15, IL-18, TNF-a, } \\
\text { G-CSF, GM-CSF, MCSF, Gro, } \\
\text { MIP-2 (mouse), IP-10, RANTES, } \\
\text { MCP-1, TGF- } \alpha, \text { TGF- } \beta\end{array}$ \\
\hline Langerhans cells & $\begin{array}{l}\text { IL-1a, IL-1 } \beta, \text { IL-6, IL-15, IL-18, } \\
\text { TNF- } a, \text { Gro, MIP-2, MIP-1a, } \\
\text { TGF- } \beta\end{array}$ \\
\hline Melanocytes & $\begin{array}{l}\text { IL-1 } \alpha, \text { IL-1 } \beta, \text { IL-6, IL-7, IL-8, IL- } \\
\text { 10, IL-12, TNF- } \alpha, \text { G-CSF, GM- } \\
\text { CSF, MCSF, Gro, MIP-2 } \\
\text { (mouse), RANTES, MCP-1, } \\
\text { TGF- } \alpha, \text { TGF- } \beta\end{array}$ \\
\hline
\end{tabular}

Skin hypersensitivity reactions are the result of imbalance between a variety of types of T-cell responses and inflammatory mediators, including T-helper (Th) 2 cytokines and also T-helper 1 cells [26]. A Th1/Th2 hypothesis suggests that imbalance among these cells toward Th2 is the key to allergic reaction intensifying $[22,27]$. The Th1 cells release of pro-inflammatory cytokines includes IL-1 $a$, IL$1 \beta, I L-8, I L-13$, TNF-a, and granulocyte-macrophage colony-stimulating factor (GM-CSF). They increase the vascular permeability and cause swelling and redness associated with inflammation and immunologic reactions in skin exposed to irritants, also affect the proliferation and differentiation of keratinocytes and mediators of cellular infiltration [3, 21, 22].

The key regulators are TFN- $\alpha$ and IL-1 $\beta$. These pleiotropic cytokines are responsible for inflammation, apoptosis and necrosis of cells, phagocytic and cytotoxic activities [28].

IL-10 is an anti-inflammatory interleukin produced mainly by monocytes, T cells, macrophages, and dendritic cells. Mast cells can also produce IL-10, which limits the rate of leukocyte infiltration, inflammation, and skin disorders such as contact dermatitis [21]. IL-4 and IL- 10 suppress Th 1 immune response. IL-10 deficiency is crucial in maintaining of CD clinical signs [29].

The pro-inflammatory cytokines TNF-a and IL-1 $\beta$ and the Th1/Th2 cytokines IFNy and IL-4 are involved in both the induction and elicitation of cutaneous immune response and are modulated by glucocorticoids, that is also proved by the results of our study. Glucocorticoids decrease TNF- $\alpha$ and IL-1 $\beta$ production and shift the Th1/Th2 ratio in a Th2 direction by augmenting production of IL-4 $[16,30]$. Mechanisms of such imbalance are associated with activation of oxidative stress, which is realized by generation of reactive oxygen and nitric species (ROS and RNS) and depletion of antioxidant defense. 'Vicious circle' is running here: low antioxidant indices intensify the release of cytokines and inflammation processes that promotes the generation of ROS and RNS again.

Use of nano-encapsulated medications is emerging as potential therapeutics for a wide variety of diseases [22]. They have been successfully used for delivery of hydrophobic and hydrophilic small molecule drugs and biomacromolecules, nucleic acids of various sizes and structures. It is very important for skin diseases treatment to go through the stratum corneum to target tissues and subcellular compartments and nanoparticles are quite 
successive for that. Nano-form of preparations, especially its combination was the most powerful to alleviate experimental contact dermatitis clinical sings and intensity of oxidative and nitro-oxidative stress [31, 32].

Our previous findings proved the importance of oxidative and nitro-oxidative stress activation in pathogenesis of CD. The last one is aggravated by cytokines. Nitric oxide synthase (NOS) is an enzyme that catalyzes the synthesis of NO and L-citrulline using oxygen and L-arginine as substrates. And its isoform iNOS is induced by the cytokines TNF-a, IL-1 [33].

So, modulation of NO-synthase (NOS) activity, use of antioxidants and free radical scavengers are important and prospect part of complex treatment for different types of CD (plus common recommendations for allergens avoiding, emollients and others) $[2,33,35]$. The perspective results of combined treatment with betamethasone-, SOD (superoxide dismutase) and 1400W (highly selective inhibitor of inducible nitric-oxide synthase, iNOS)-loaded nanoparticles were obtained. Such combination of the potent anti-inflammatory steroid agent, the powerful antioxidant and iNOS-inhibitor in nanoencapsulated form was more effective in experimental contact dermatitis than use of their free forms [31, 36].

\section{Conclusions}

Experimental contact dermatitis induced by $5 \%$ nickel sulfate is accompanied by pathological cytokines imbalance. Mono-treatment with betamethasone, SOD (superoxide dismutase) and 1400W (highly selective inhibitor of inducible nitric-oxide synthase, iNOS) was efficient, but the use of nanoparticles loaded with these agents surpassed its effects. The use of combination of all nanoencapsulated medicines was the most effective.

Chitosan nanoparticles loaded with topical anti-inflammatory glucocorticoid, and inhibitors of oxidative and nitro-oxidative stress is a promising method for treatment of allergic contact dermatitis and can be recommended for further research and use in clinics.

\section{Acknowledgments}

The Research was conducted as a part of Scientific Investigation and Research 0112 U000542 "Biochemical mechanisms of toxicity of nanoparticles of different origin and other anthropogenic and biogenic toxicants and biological systems" and 0116 U003353 "Biochemical mechanisms of metabolism disorders in case of body intake of toxicants of different genesis".

\section{ЦИТОКІНОВИЙ ПРОФІЛЬ ПРИ ЕКСПЕРИМЕНТАЛЬНОМУ КОНТАКТНОМУ ДЕРМАТИТІ ТА ВИКОРИСТАННІ НАНОІНКАПСУЛЬОВАНИХ ПРЕПАРАТІВ}

I. І. Худан-Цільо, О. О. Шевчук, М. М. Корда ТЕРНОПІЛЬСЬКИЙ ДЕРЖАВНИЙ МЕДИЧНИЙ УНІВЕРСИТЕТ ІМЕНІ І. Я. ГОРБАЧЕВСЬКОГО, ТЕРНОПІЛЬ, УКРАЇНА

Вступ. Запалення, оксидативний та нітрооксидативний стрес $є$ основою патогенезу контактного алергічного дерматиту та розвитку дисбалансу цитокінів.

Мета дослідження полягала у вивченні змін цитокінів TNF-a, IL-1ß, IL-4 і IL-10 в сироватці крові щурів 3 контактним нікель-індукованим дерматитом при використанні вільних і наноінкапсульованих препаратів бетаметазону, супероксиддисмутази (СОД) і потужного високоселективного інгібітора iNOS (1400W).

Методи. Для моделювання контактного дерматиту (КД) 5\% сульфат нікелю наносили на шкіру щурам протягом 12 днів. Білі щури-самці масою тіла 180-220 г було рандомізовано на 10 груп $(n=10)$ : I група - контрольна; II - тварини з КД; III - щури з КД, які отримували полімерні хітозанові наночастинки; IV - VI групи - щури з КД, які отримували вільні форми СОД, 1400W та бетаметазону відповідно; VII-IX групи - щури, яким вводили наноСОД, нано-1400W $i$ нано-бетаметазон; Х група - КД + нанокомпозиція всіх препартів корекції.

Результати дослідження. Доведено, що при експериментальному контактному дерматиті достовірно зростає рівень прозапальних цитокінів TNF-a, IL-1 зі здоровими щурами. Монотерапія препаратами бетаметазону, СОД і 1400W є ефективною, однак використання нанаінкапсульованих форм перевищує результати монозастосування кожного препарату. Найбільш ефективним $\epsilon$ використання поєднання всіх наноінкапсульованих лікарських засобів.

Висновки. Хітозанові наночастинки з інкапсульованими препаратами топічного протизапального глюкокортикоїда та інгібіторів оксидативного і нітрооксидативного стресу є перспективним методом лікування контактного дерматиту і можуть бути рекомендовані для подальшого вивчення з впровадженням у клінічну практику.

КЛЮЧОВІ СЛОВА: контактний нікелевий дерматит; цитокіни; наночастинки; бетаметазон; СОД; $1400 \mathrm{~W}$. 


\section{References}

1. Peiser M, Tralau T, Heidler J, Api AM, Arts JHE, Basketter DA, et al. allergic contact dermatitis: epidemiology, molecular mechanisms, in vitro methods and regulatory aspects. Cell Mol Life Sci 2012;69:763-81. doi:10.1007/s00018-011-0846-8.

2. BraschJ, Becker D, AbererW, Bircher A, Kränke B, Jung $K$, et al. Guideline contact dermatitis. [German]. Allergo J 2014;23:30-43. doi:http://dx.doi. org/10.1007/s40629-014-0013-5.

3. Martin SF, Esser PR, Weber FC, Jakob T, Freudenberg MA, Schmidt M, et al. Mechanisms of chemical-induced innate immunity in allergic contact dermatitis. Allergy Eur J Allergy Clin Immunol $2011 ; 66: 1152-63$. doi:10.1111/j.1398-9995. 2011.02652.x.

4. $\lim \mathrm{HW}$, Collins SAB, Resneck JS, Bolognia JL, HodgeJA, RohrerTA, et al. The burden of skin disease intheUnitedStates.JAmAcadDermatol2017;76:958972.e2. doi:10.1016/j.jaad.2016.12.043.

5. Caplan A, Fett N, Rosenbach M, Werth VP, Micheletti RG. Prevention and management of glucocorticoid-induced side effects: A comprehensive review: Gastrointestinal and endocrinologic side effects. J Am Acad Dermatol 2017;76:11-6. doi:10.1016/j.jaad.2016.02.1241.

6. Dhar S, Seth J, Parikh D. Systemic side-effects of topical corticosteroids. Indian J Dermatol 2014;59:460-4. doi:10.4103/0019-5154.139874.

7. Rahimi N. Defenders and Challengers of Endothelial Barrier Function. Front Immunol 2017;8:1847. doi:10.3389/fimmu.2017.01847.

8. Abdel-Mottaleb MM, Try C, Pellequer $Y$, lamprecht A, Abdel MMA, Abdel-Mottaleb MM, et al. Nanomedicine strategies for targeting skin inflammation. Nanomedicine 2014;9:1727-43. doi:10.2217/nnm.14.74.

9. Bhatia S. Natural polymer drug delivery systems: Nanoparticles, plants, and algae. 2016. doi:10.1007/978-3-319-41129-3.

10. Siddique MI, Katas $\mathrm{H}$, Amin MCIM, Ng S-F, Zulfakar $\mathrm{MH}$, Buang $\mathrm{F}$, et al. Minimization of local and Systemic Adverse Effects of Topical Glucocorticoids by Nanoencapsulation: In Vivo Safety of Hydrocortisone-Hydroxytyrosol Loaded Chitosan Nanoparticles. J Pharm Sci 2015;104:4276-86. doi:10.1002/jps.24666.

11. Fontana MC, Rezer JFP, Coradini K, Leal DBR, Beck RCR. Improved efficacy in the treatment of contact dermatitis in rats by a dermatological nanomedicine containing clobetasol propionate. Eur J Pharm Biopharm 2011;79:241-9. doi:10.1016/j. ejpb.2011.05.002.

12. Coondoo A, Phiske M, verma S, lahiri K. Sideeffects of topical steroids: A long overdue revisit. Indian Dermatol Online J $2014 ; 5: 416-25$ doi:10.4103/2229-5178.142483.

13. Akdis M, Aab A, Altunbulakli C, Azkur K, Costa RA, Crameri R, et al. Interleukins (from IL-1 to IL-38), interferons, transforming growth factor $\beta$, and TNF-a: Receptors, functions, and roles in diseases. J Allergy Clin Immunol 2016; 138: 984-1010. doi:10.1016/j.jaci.2016.06.033.
14. Xiao Z, Xiao S, Zhang Y, Pan T, Ouyang B. The Anti-Inflammatory Effect of Fructus Kochiae on Allergic Contact Dermatitis Rats via pERK1/2/TLR4/ NF-kB Pathway Activation. Evidence-Based Complement Altern Med 2018; 2018:1-12. doi:10.1155/2018/1096920.

15. Hussain Z, Katas $H$, Mohd Amin MCI, Kumolosasi E, Buang F, Sahudin S. Self-assembled polymeric nanoparticles for percutaneous codelivery of hydrocortisone/hydroxytyrosol: An ex vivo and in vivo study using an NC/Nga mouse model. Int J Pharm 2013;444:109-19. doi:10.1016/j. ijpharm.2013.01.024.

16. Bechara R, Antonios D, Azouri H, Pallardy M. nickel Sulfate Promotes IL-17A Producing Cd4+ T Cells by an IL-23-Dependent Mechanism Regulated by TLR4 and Jak-STAT Pathways. J Invest Dermatol 2017;137:2140-8. doi:10.1016/j.jid.2017.05.025.

17. Kolesnik M, Franke I, Lux A, Quist SR, Gollnick HP. Eczema in Psoriatico: An important differential Diagnosis Between Chronic Allergic Contact Dermatitis and Psoriasis in Palmoplantar Localization. Acta Derm Venereol 2018;98:50-8. doi:10.2340/00015555-2779.

18. Lagrelius $M$, Wahlgren C-F, Matura $M$, Bergström A, Kull I, Lidén C. A population-based study of self-reported skin exposures and symptoms in relation to contact allergy in adolescents. Contact Dermatitis 2017;77:242-9. doi:10.1111/cod.12816.

19. Yamaguchi $H$, Kabashima-Kubo $R$, Bito $T$, Sakabe J Ichi, Shimauchi T, Ito T, et al. High frequencies of positive nickel/cobalt patch tests and high sweat nickel concentration in patients with intrinsicatopicdermatitis.J DermatolSci2013;72:240- 5. doi:10.1016/j.jdermsci.2013.07.009.

20. Khan M, Rani Z, Ahmed M, Hussain I. Evaluation and pattern of nickel dermatitis in patients with allergic contact dermatitis. J Pakistan 2016;15:136-9.

21. Bordignon v, Palamara $F$, Altomonte $G$, Sperduti I, Pietravalle M, Cavallotti C, et al. A laboratory test based on determination of cytokine profiles: a promising assay to identify exposition to contact allergens and predict the clinical outcome in occupational allergic contact dermatitis. BMC immunol 2015;16:4. doi:10.1186/s12865-015-0066-3.

22. Elsabahy M, Wooley KL. Cytokines as biomarkers of nanoparticle immunotoxicity. Chem Soc Rev 2013;42:5552-76. doi:10.1039/c3cs60064e.

23. Cruz CM, Rinna A, Forman HJ, Ventura ALM, Persechini PM, Ojcius DM. ATP activates a reactive oxygen species-dependent oxidative stress response and secretion of proinflammatory cytokines in macrophages. J Biol Chem 2007;282:2871-9. doi:10.1074/jbc.M608083200.

24. Corsini E, Galli CL. Epidermal cytokines in experimental contact dermatitis. Toxicology 2000;142: 203-11. doi:10.1016/S0300-483x(99)00145-6.

25. Saint-Mezard P, Krasteva M, Chavagnac C, Bosset S, Akiba $\mathrm{H}$, Kehren J, et al. Afferent and Efferent Phases of Allergic Contact Dermatitis (ACD) 
Can Be Induced After a Single Skin Contact with Haptens: Evidence using a Mouse Model of Primary ACD. J Invest Dermatol 2003;120:641-7. doi:10.1046/ j.1523-1747.2003.12093.x.

26. Pucheu-Haston CM, Bizikova P, Marsella $R$, Santoro D, Nuttall T, Eisenschenk MNC. Review: Lymphocytes, cytokines, chemokines and the T-helper 1-T-helper 2 balance in canine atopic dermatitis. Vet Dermatol 2015;26:124-e32. doi:10.1111/vde.12205.

27. Baranova NI, Kozhenkova SV, Ashchina LA. Role of regulatory $T$ cells in pathogenesis of allergic diseases. Cytokines and inflammation. 2015;14:12-6 [In Russian].

28. Alshevskaya AA, lopatnikova YuA, Shkaruba NS, Chumasova OA, Sizikov AE, Krugleeva OL, Nepomnyashchikh VM, Vasilyev FF, Sennikov SV. The expression of membrane-bound TNFa receptors on monocytes in atopic dermatitis and rheumatoid arthritis. Cytokines and inflammation. 2015;14:18-23. [In Russian]

29. Smolnikova MV, Smirnova SV, Barilo AA, Epaneshnikova VB. Cytokine gene polymorphisms of C-590T IL-4 and C-597A IL-10 and serum concentrations of IL-4 and IL-10 in psoriasis and psoriatic arthritis. Cytokines and Inflammation. 2016;15:74-80 [in Russian].

30. Jensen LE. Targeting the IL-1 family members in skin inflammation. Curr Opin Investig Drugs 2010;11:1211-20.
31. Khudan-Tsilo II, Shevchuk OO, Korda MM. Topical treatment of contact nickel dermatitis: capasity of nanoencapsulated superoxide dismutase. Bulletin of Scientifiic Data 2017;4:140-4 [in Ukrainian].

32. Khudan-Tsilo II, Korda MM. Structural changes in contact nickel dermatitis in case of suppressing of iNOS. Achievements of Clinical and Experimental Medicine. 2017;3:165-9. doi:10.11603/1811-2471.2017.v1.i3.8177 [in Ukrainian].

33. Wilsmann-Theis D, Koch S, Mindnich C, Bonness S, Schnautz S, von Bubnoff D, et al. Generation and functional analysis of human TNF-a/ iNOS-producing dendritic cells (Tip-DC). Allergy 2013;68:890-8. doi:10.1111/all.12172.

34. Eichenfield LF, Tom WL, Berger TG, Krol A, Paller AS, Schwarzenberger K, et al. Guidelines of Care for the Management of Atopic Dermatitis: Part 2: Management and treatment of atopic dermatitis with Topical Therapies. J Am Acad Dermatol 2014;71:116-32. doi:10.1016/j.jaad. 2014.03.023.

35. Lo Faro ML, Fox B, Whatmore JL, Winyard PG, Whiteman M. Hydrogen sulfide and nitric oxide interactions in inflammation. Nitric Oxide 2014;41:38-47. doi:10.1016/j.niox.2014.05.014.

36. Khudan-Tsilo II, Korda MM. Nano-form of superoxide dismutase - perspective method of treatment of contact dermatitis. Bulletin of Scientific Data 2017;3:144-8. doi:10.11603/2415-8798. 2017.3.8135 [In Ukrainian]. 